\title{
Lifestyle and Spiritual Practices of Generation Z
}

Jamiah Manap, Salasiah Hanin Hamjah, Fazilah Idris, Arena Che Kasim \& Ruszymah Idrus

To Link this Article: http://dx.doi.org/10.6007/IJARBSS/v11-i6/10222

DOI:10.6007/IJARBSS/v11-i6/10222

Received: 10 April 2021, Revised: 13 May 2021, Accepted: 30 May 2021

Published Online: 16 June 2021

In-Text Citation: (Manap et al., 2021)

To Cite this Article: Manap, J., Hamjah, S. H., Idris, F., Kasim, A. C., \& Idrus, R. (2021). Lifestyle and Spiritual Practices of Generation Z. International Journal of Academic Research in Business and Social Sciences, 11(6), 909-923.

\section{Copyright: (c) 2021 The Author(s)}

Published by Human Resource Management Academic Research Society (www.hrmars.com)

This article is published under the Creative Commons Attribution (CC BY 4.0) license. Anyone may reproduce, distribute, translate and create derivative works of this article (for both commercial and non-commercial purposes), subject to full attribution to the original publication and authors. The full terms of this license may be seen

at: http://creativecommons.org/licences/by/4.0/legalcode

\section{Vol. 11, No. 6, 2021, Pg. 909- 923}

Full Terms \& Conditions of access and use can be found at http://hrmars.com/index.php/pages/detail/publication-ethics 


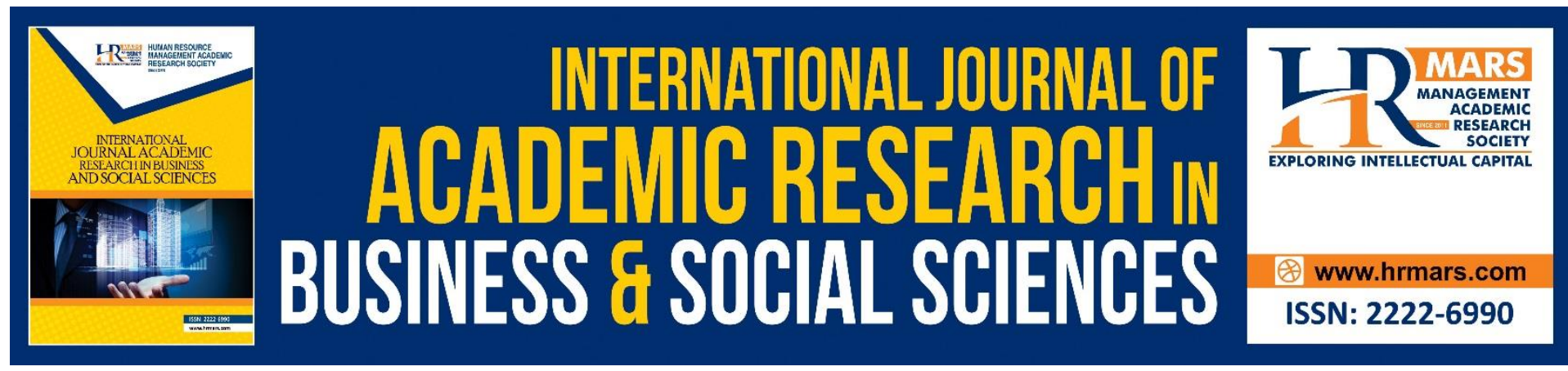

\title{
Lifestyle and Spiritual Practices of Generation Z
}

\author{
Jamiah Manap ${ }^{1}$, Salasiah Hanin Hamjah², Fazilah Idris ${ }^{3}$, \\ Arena Che Kasim ${ }^{1}$ \& Ruszymah Idrus ${ }^{4}$
}

${ }^{1}$ Center for Research in Psychology and Human Well-Being, Faculty of Social Science and Humanities, The National University of Malaysia, 43600 Bangi, Selangor, Malaysia,

${ }^{2}$ Centre for Human and Community Well-being, Faculty of Islamic Studies, Universiti Kebangsaan Malaysia (UKM), 43600 Bangi, Selangor, ${ }^{3}$ Centre for Liberal Studies Universiti Kebangsaan Malaysia (UKM), 43600 Bangi, Selangor, ${ }^{4}$ Faculty of Medicine Universiti Kebangsaan Malaysia (UKM), 43600 Bangi, Selangor

Email: jamiah@ukm.edu.my

\begin{abstract}
Lifestyle reflects how a person spends his time in daily routine and life. A lifestyle which does not adhere to spiritual values may compromise a person's well-being such as engaging in illegal street racing, free sex and gangsterism. This research aimed to identify the lifestyle activities of Generation Z, study their spiritual practices and analyze the relationship between the lifestyle activities and spiritual practices among Gen $Z$. This research is designed as a survey study. The main research instrument is questionnaire. Respondents are selected by stratified random sampling involving 673 Malaysian adolescents. The results showed that Gen $Z$ are very concerned with personal hygiene. The spiritual practices most observed by Gen Z are solah, fasting, doa and being grateful. The research found that there is a significant relationship between lifestyle activities and spiritual practices among Gen Z. Spiritual practices have a positive impact on Gen Z's lifestyle and well-being.
\end{abstract}

Keywords: Lifestyle, Spiritual, Religion, Well-Being, Adolescent, Gen Z.

\section{Introduction}

The word lifestyle appears only in the modern world. It describes a combination of knowledge, thought, perception, experience, emotion and actions of a person (Adler 1956; Brunso et al., 2004). It is defined as a way of life and how a person spends his money and time (Engel et al., 1995). In other words, lifestyle usually reflects a person's attitude, values and views of his world. Basically, there are various human lifestyles such as modern, hedonistic and consumer lifestyles (Tarigan, 2015; Safuwan, 2007; Puaca, Theandersson \& Carlen, 2017). A modern lifestyle is more concerned with the latest, a hedonistic lifestyle is more concerned with entertainment and a consumer lifestyle refers to an individual who spends excessively causing wastage and buying less needed items.

Spiritual practices are also frequently known as religious practices. The spiritual entity according to al-Ghazali is signified by each of the four elements, that is, al-ruh (soul), al-qalb (heart), al-'aql (Intellect/reason) and al-nafs (desire-nature) (al-Ghazali, 2000). All of these terms explain that the spiritual aspect is ma'nawi (meaning-related), not visible but 
concealed in the human heart and psyche. Hence, spiritual practice is related to the heart and psyche which is not visible to the eye but its implementation may be seen by the senses, for example, solat (prayer), recitation of al-Quran, fasting, paying zakat (charity tax), qiyamullail (night prayers) and so on. Gen Z in Malaysia refers to individuals born between the years 1994-2010. This generation is said to be as if genetically internet from birth. The reason is that they were born when internet first began to be widely used in the whole world (Manap et al., 2015). They are internet and IT application literate. Generally, Gen $Z$ is between age 8 to 24 years old in the year 2018. On average, Gen Z is in lower primary school up to almost or has completed university education. In a study by Tapscott (2008), Gen Z was born between the years 1998 to 2009. Gen Z is a technology generation. Those in the Gen Z started surfing internet and web since before they were able to talk, having been exposed, guided and encouraged by parents to use world or social networking site since young. Gen Z is more inclined to grow up in a world where everything is through technology from an early developmental stage of their lives.

There are various lifestyles practised by Gen $Z$ today. This is alarming as among them are those who are stuck with a bad lifestyle and are involved with social problems such as LGBT (Ahmad et al. 2015; Hafford-Letchfield et al. 2018; Raifman 2018; Almeida et al., 2009), drug addiction (Don, 2000; Jaafar et al., 2014), prostitution (Hasan, 1998; Tohri, 1998), illegal street racing (Tahir et al., 2017; Wong, 2011), baby dumping (Abdullah, 2014; Mohd \& Alkali, 2015) and so on, which affect their well-being and social harmony. Unhealthy lifestyles were shown by students through findings in a study by Hong et. al (2011) at 11 secondary schools in Sarawak. Research findings showed that a high number of students were involved in substance abuse such as alcohol and cigarettes, involving a quarter of the whole population of 6798 students. However, not all of Gen Z lead an unhealthy lifestyle, in fact many among them lead a healthy lifestyle and emphasize on spiritual practices in their lives on the assumption that such practices may bring peace and happiness in the face of whatever challenges in life (Dedeli et al., 2015; Carr \& Kroth, 2017; Egan et al., 2017; Klingle \& Van Vliet, 2019). Hence, this research generally aims to determine if there is a relationship between lifestyle and spiritual practices of Gen Z as basically human well-being depends very much on lifestyle.

Generally, there have been researches done on lifestyle but mostly on lifestyle relating to medical and healthcare. For example, a study was done on lifestyle and human cardiac health (Papaioannou et al., 2017; Kapelios et al., 2017; Li et al., 2016), osteoporosis (Lotfi, 2017), diabetes (Fareed et al., 2017), Parkinson's disease (Ueki \& Otsuka, 2004), and cancer (Spitz et al., 2017; Bilal \& Padilla, 2016; Mourouti et al., 2015). Still about health, more researches have been done relating to the obesity problem. One of them is a study by Miri et al (2017) which found that obese teenagers were less likely to perform physical activity in their lifestyle. In another study, Pjanic et al (2017) found that the obesity problem may be overcome through emotional management skills and reducing of depression symptoms. A study by Hou et al. (2017); Lau et al (2019); Yusop (2018) found that a change in lifestyle especially in selection of foods and doing physical activities may reduce obesity and heart problems. A study by Shinohara et al. 2017 found that lifestyle and eating habits affect the quality of life and learning attitude of children. 
There are also studies done on lifestyle and psychology such as that by Gonzalez-Hernandez et al (2017) which found that human psychological well-being and personality are related to physical activity. In line with technology era, there are also studies done on lifestyle and cyberworld internet addiction, such as that by Shrivastava et al (2018) which found that internet addiction affected productivity and work procrastination. In addition to health, psychology and communication, studies were also done on lifestyle related to socio-economy and oral hygiene such as that done by Cankovic et al (2016). In addition to studying aspects of lifestyle, this research also studies spiritual practices among adolescents of Gen Z. Past research shows there have been studies on spiritual practices such as that by Egan et al. (2017) which found that spiritual practices are needed as palliative by terminal patients to achieve peace of mind. This finding is in line with a study by Dedeli et al (2015) which found that spiritual practices are important among cancer patients to achieve peace of mind in the final moments to face death.

Other studies also clearly showed the importance of spiritual practices in various life situations such as that done by Wendt et al (2017) concerning spiritual practices among the homeless which found that respondents who were increasingly frequent doing spiritual practices became increasingly less addicted to alcohol. A study by Carr \& Kroth (2017) found that spiritual practices such as solah (prayer), fasting, ibadah (acts of devotion) helped a person to get closer to God and this was self-transformation process. Besides that, a study by Ramachandran et al (2017) found that spiritual intelligence of academic women leaders gave a positive impact on the sustainability of the institution, high moral values and reduced ethical issues. On the whole, spiritual practices improved work situations to become more meaningful and harmonious. Generally, findings of past studies show that spiritual practices are important in various life situations including patients with chronic diseases (Egan et al., 2017; Dedeli et al., 2015; Guz et al., 2012; Corn et al., 2012; Thune-Boyle et al., 2012), workers (Ramachandran et al., 2017), the elderly (Whelan-Gales et al., 2009; Kawahara \& Yuki, 2001), trainee counselors (Ghazali et al., 2017) students (Musa, 2015) and so on. Findings of past studies show that no study has been done to relate lifestyle with spiritual practices among the Gen Z. This clearly shows that such a study needs to be done more in-depth. Thus the objectives of this research was to analyse the relationship between lifestyle activities and spiritual practices among Gen Z.

\section{Methodology \\ Participants and Procedure}

Respondents were selected by stratified random sampling according to zones in Malaysia. Research involved 755 adolescents aged between 13 to 21 years. They can divided into three categories: lower secondary school, upper secondary school and college/university student. Most of them comes are Malay and comes from lower income family group (B40). In order to conduct this research, informed consent was taken from all the participants. The participants were briefed about the research. Anonymity of the participants as well as confidentiality of the data was maintained. Pilot test have been made before the actual test. The reliability scale for healthy lifestyle is 0.67 , meanwhile the reliability scale for spiritual practice is 0.91 .

\section{Measure}

This research is designed as a study survey. Questionnaire is the main research instrument. It forms part of the Gen Z Profile (G-Z) questionnaire constructed by Jamiah et al. (2016). 
Measurement of Healthy Lifestyle comprises of six items. The item focus on cleanliness, eating habit, sleeping pattern, physical activity, and health screening. The response for the items were answered using 5 point Likert Scale, i.e., Very Frequently, Frequently, Sometimes, Occasionally and Never. Spiritual practices contain 13 items and response was answered in the form of 10 point scale, i.e. 0-10 to represent level of frequency i.e. never to very frequently. The items focus on religious ritual and religious practice in daily life.

\section{Data Analysis}

Data were analysed using descriptive statistical technique that are percentage, frequency and mean. In this study, data were coded to identify activities of Gen $Z$ and analyse relationship between lifestyle and spiritual practices among Gen Z. The data from questionnaires were coded into Statistical Package for Social Sciences (SPSS) version 22.0. Research results were interpreted in a table containing percentage, frequency and mean.

\section{Results and Discussion}

Adolescents in this research are very much concerned with personal hygiene which achieved the highest mean value (mean=3.97), followed by concern for a balanced diet (carbohydrates, proteins, vitamins, according to food pyramid) (mean=3.52) and keeping sufficient sleep hours (mean=3.43) as their lifestyle activities (Table 1). This finding shows that Gen $Z$ in this research are concerned about personal hygiene (mean=3.97). This practice, if continued as lifestyle of Gen Z adolescents, promises success for their well-being. This finding, however differs from the situation in Nepal, particularly in the aspect of personal hygiene among menstruating women during a natural disaster. Shortage of sanitary supplies caused personal hygiene to be neglected (Budhathoki et al., 2018). This finding also differs from that in a study by Peltzer \& Pengpid (2014) concerning oral hygiene and cleanliness of hands of students aged between 13 to 15 years in four South-east Asian countries, i.e., India, Indonesia, Myanmar and Thailand. The research found that only $22.4 \%$ of school-children brushed their teeth twice daily and $45.2 \%$ did not wash their hands before eating. This finding shows that adolescents in South-east Asia are still weak or neglectful in keeping cleanliness of hands and mouth. This situation is uncommon in Malaysia because of cleanliness campaigns which are continuously held since kindergarten and primary school. Malaysia once celebrated World Hygiene Day 2016 at the National Level with the theme See Your Hand: Hand Hygiene Supports Safe Surgical Care to raise awareness among her citizens to keep their hands clean as a simple first step in prevention and avoiding disease infection (Zin, 2016).

Even though this research finds respondents keep their sleeping hours, this finding seems to contradict another study by Chang et al (2018) which found that many adolescents face difficulty in sleeping at night. A study by Van der Schuur et al (2018) found that adolescents involved in media multi-tasking also faced sleep disorders. Adolescents who experienced sleep disorders also have a higher relationship with anxiety disorders (Palmer et al., 2018). This finding clearly shows that adolescents who are still young already have sleep disorders whereas usually sleep disorder is often experienced by adults and elderly people (Amir, 2007; Yu et al., 2017; Sagayadevan et al., 2017). 
Table 1: Lifestyle Activity

\begin{tabular}{|c|c|c|c|c|c|c|c|}
\hline $\begin{array}{l}\text { Lifestyle } \\
\text { activity }\end{array}$ & $\begin{array}{c}\text { Neve } \\
r\end{array}$ & Once & $\begin{array}{c}\text { Sometime } \\
\mathrm{s}\end{array}$ & $\begin{array}{c}\text { Frequentl } \\
y\end{array}$ & $\begin{array}{c}\text { Very } \\
\text { Frequentl } \\
y \\
\end{array}$ & $\begin{array}{c}\text { Responden } \\
\text { t did not } \\
\text { answer }\end{array}$ & $\begin{array}{c}\text { Mea } \\
n\end{array}$ \\
\hline $\begin{array}{l}\text { Personal } \\
\text { hygiene }\end{array}$ & $\begin{array}{c}29 \\
3.8 \%\end{array}$ & $\begin{array}{c}32 \\
4.2 \%\end{array}$ & $\begin{array}{c}123 \\
16.3 \%\end{array}$ & $\begin{array}{c}261 \\
34.6 \%\end{array}$ & $\begin{array}{c}298 \\
39.5 \%\end{array}$ & $\begin{array}{c}12 \\
1.6 \%\end{array}$ & 3.97 \\
\hline $\begin{array}{l}\text { Eat balanced } \\
\text { diet } \\
\text { carbohydrate } \\
\text {, protein, } \\
\text { vitamins } \\
\text { according to } \\
\text { food } \\
\text { pyramid) }\end{array}$ & $\begin{array}{c}18 \\
2.4 \%\end{array}$ & $\begin{array}{c}34 \\
4.5 \%\end{array}$ & $\begin{array}{c}333 \\
44.1 \%\end{array}$ & $\begin{array}{c}256 \\
33.9 \%\end{array}$ & $\begin{array}{c}110 \\
14.6 \%\end{array}$ & $\begin{array}{c}4 \\
0.5 \%\end{array}$ & 3.52 \\
\hline $\begin{array}{l}\text { Sufficient } \\
\text { sleeping } \\
\text { hours (7-8 } \\
\text { hours } \\
\text { nightly) }\end{array}$ & $\begin{array}{c}23 \\
3.0 \%\end{array}$ & $\begin{array}{c}39 \\
5.2 \%\end{array}$ & $\begin{array}{c}365 \\
48.3 \%\end{array}$ & $\begin{array}{c}215 \\
28.5 \%\end{array}$ & $\begin{array}{c}107 \\
14.2 \%\end{array}$ & $\begin{array}{c}6 \\
0.8 \%\end{array}$ & 3.43 \\
\hline Eat on time & $\begin{array}{c}36 \\
4.8 \%\end{array}$ & $\begin{array}{c}61 \\
8.1 \%\end{array}$ & $\begin{array}{c}324 \\
42.9 \%\end{array}$ & $\begin{array}{c}219 \\
29.0 \%\end{array}$ & $\begin{array}{c}109 \\
14.4 \%\end{array}$ & $\begin{array}{c}6 \\
0.8 \%\end{array}$ & 3.38 \\
\hline $\begin{array}{l}\text { Do physical } \\
\text { activity at } \\
\text { least } 30 \\
\text { minutes daily }\end{array}$ & $\begin{array}{c}39 \\
5.2 \%\end{array}$ & $\begin{array}{c}124 \\
16.4 \\
\%\end{array}$ & $\begin{array}{c}316 \\
41.9 \%\end{array}$ & $\begin{array}{c}177 \\
23.4 \%\end{array}$ & $\begin{array}{c}92 \\
12.2 \%\end{array}$ & $\begin{array}{c}7 \\
0.9 \%\end{array}$ & 3.18 \\
\hline $\begin{array}{l}\text { Eat health } \\
\text { food }\end{array}$ & $\begin{array}{c}27 \\
3.6 \%\end{array}$ & $\begin{array}{c}108 \\
14.3 \\
\%\end{array}$ & $\begin{array}{c}389 \\
51.5 \%\end{array}$ & $\begin{array}{c}158 \\
20.9 \%\end{array}$ & $\begin{array}{c}68 \\
9.0 \%\end{array}$ & $\begin{array}{c}5 \\
0.7 \%\end{array}$ & 3.15 \\
\hline $\begin{array}{l}\text { Health } \\
\text { screening } \\
\text { checks }\end{array}$ & $\begin{array}{c}94 \\
12.5 \\
\%\end{array}$ & $\begin{array}{c}196 \\
26.0 \\
\%\end{array}$ & $\begin{array}{c}369 \\
48.9 \%\end{array}$ & $\begin{array}{c}64 \\
8.5 \%\end{array}$ & $\begin{array}{c}25 \\
3.3 \%\end{array}$ & $\begin{array}{c}7 \\
0.9 \%\end{array}$ & 2.61 \\
\hline
\end{tabular}

This research also finds that many respondents among Gen Z (366 persons, 48.5\%) admitted to frequently and very frequently taking a balanced diet. This shows research respondents are very concerned with taking a balanced diet for healthcare. This finding differs from a study by Patimah et al (2016) in Indonesia which found that $41 \%$ of respondents had a low knowledge about balanced diet and $46.5 \%$ of them had a very low practice of taking a balanced diet such that an intervention approach about balanced diet needed to be done for female adolescents to create awareness of the importance of healthcare through a balanced diet. Research results finds that Gen $\mathrm{Z}$ are also concerned about physical health because a 
number of them eat their meals on time (mean=3.38) and do physical activity at least 30 minutes daily (mean=3.18). There are among them who also take health foods (mean=3.15) and do health screening checks (mean=2.61). Research findings are in line with findings of a study by Husain (2009) which found that respondents had a positive perception of healthcare and nutrition in a healthy lifestyle in line with Islamic teachings. They also gave a good feedback on implementation of healthcare and nutrition such as health food, recreation, prayer, and fasting in daily life.

Research results shows that majority of Gen Z take their meals on time (mean=3.38). This is a good life style because eating on time has direct influence one's health. One should not leave the breakfast because missing breakfasts has been associated with the incidence of childhood obesity (Thompson-McCormick et al., 2010). In Islam, a healthy body is paramount as the means to worship Allah in order to achieve both religious and worldly achievement. Therefore, it is crucial for a muslim to take care of his body and organs to the best of his abilities (Ahmad, 2019).

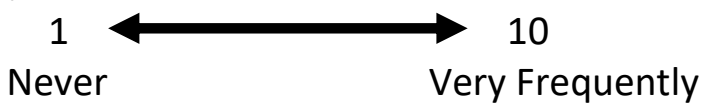

Table 2: Spiritual Practices of Gen Z

\begin{tabular}{|c|c|c|c|c|c|c|c|c|c|c|c|c|}
\hline Practice & 1 & 2 & 3 & 4 & 5 & 6 & 7 & 8 & 9 & 10 & $\begin{array}{c}\text { No } \\
\text { Answer }\end{array}$ & $\begin{array}{c}\text { Mea } \\
\mathrm{n}\end{array}$ \\
\hline \multirow[t]{4}{*}{ Prayer } & 3 & 5 & 8 & 4 & 60 & 22 & 44 & 88 & 138 & 34 & 36 & 8.22 \\
\hline & 0.4 & 0.7 & 1.1 & 0.5 & 7.9 & 2.9 & 5.8 & 11.7 & 18.3 & 7 & $4.8 \%$ & \\
\hline & $\%$ & $\%$ & $\%$ & $\%$ & $\%$ & $\%$ & $\%$ & $\%$ & $\%$ & 46 & & \\
\hline & & & & & & & & & & $\%$ & & \\
\hline \multirow[t]{4}{*}{ Fasting } & 13 & 7 & 1 & 6 & 57 & 22 & 41 & 102 & 121 & 34 & 42 & 8.07 \\
\hline & 1.7 & 0.9 & 0.1 & 0.8 & 7.5 & 2.9 & 5.4 & 13.5 & 16.0 & 3 & $5.6 \%$ & \\
\hline & $\%$ & $\%$ & $\%$ & $\%$ & $\%$ & $\%$ & $\%$ & $\%$ & $\%$ & 45. & & \\
\hline & & & & & & & & & & $4 \%$ & & \\
\hline Supplicato & 5 & 5 & 6 & 12 & 60 & 35 & 66 & 92 & 132 & 30 & 38 & 7.97 \\
\hline \multirow[t]{3}{*}{ ry Prayer } & 0.7 & 0.7 & 0.8 & 1.6 & 7.9 & 4.6 & 8.7 & 12.2 & 17.5 & 4 & $5.0 \%$ & \\
\hline & $\%$ & $\%$ & $\%$ & $\%$ & $\%$ & $\%$ & $\%$ & $\%$ & $\%$ & 40. & & \\
\hline & & & & & & & & & & $3 \%$ & & \\
\hline Being & 5 & 5 & 11 & 13 & 52 & 48 & 84 & 129 & 120 & 25 & 38 & 7.75 \\
\hline \multirow[t]{3}{*}{ Grateful } & 0.7 & 0.7 & 1.5 & 1.7 & 6.9 & 6.4 & 11. & 17.1 & 15.9 & 0 & $5.0 \%$ & \\
\hline & $\%$ & $\%$ & $\%$ & $\%$ & $\%$ & $\%$ & $1 \%$ & $\%$ & $\%$ & 33. & & \\
\hline & & & & & & & & & & $1 \%$ & & \\
\hline Helping & 5 & 6 & 7 & 12 & 78 & 66 & 87 & 150 & 141 & 16 & 35 & 7.46 \\
\hline \multirow[t]{3}{*}{ Others } & 0.7 & 0.8 & 0.9 & 1.6 & 10. & 8.7 & 11. & 19.9 & 18.7 & 8 & $4.6 \%$ & \\
\hline & $\%$ & $\%$ & $\%$ & $\%$ & $3 \%$ & $\%$ & $5 \%$ & $\%$ & $\%$ & 22. & & \\
\hline & & & & & & & & & & $3 \%$ & & \\
\hline Think & 11 & 7 & 10 & 17 & 10 & 69 & 12 & 125 & 114 & 14 & 35 & 7.10 \\
\hline well of & 1.5 & 0.9 & 1.3 & 2.3 & 2 & 9.1 & 2 & 16.6 & 15.1 & 3 & $4.6 \%$ & \\
\hline \multirow[t]{2}{*}{ others } & $\%$ & $\%$ & $\%$ & $\%$ & 13. & $\%$ & 16. & $\%$ & $\%$ & 18. & & \\
\hline & & & & & $5 \%$ & & $2 \%$ & & & $9 \%$ & & \\
\hline \multirow[t]{2}{*}{ Honest } & 9 & 10 & 13 & 19 & 96 & 80 & 13 & 128 & 98 & 13 & 36 & 6.98 \\
\hline & & & & & & & 3 & & & 3 & $4.8 \%$ & \\
\hline
\end{tabular}




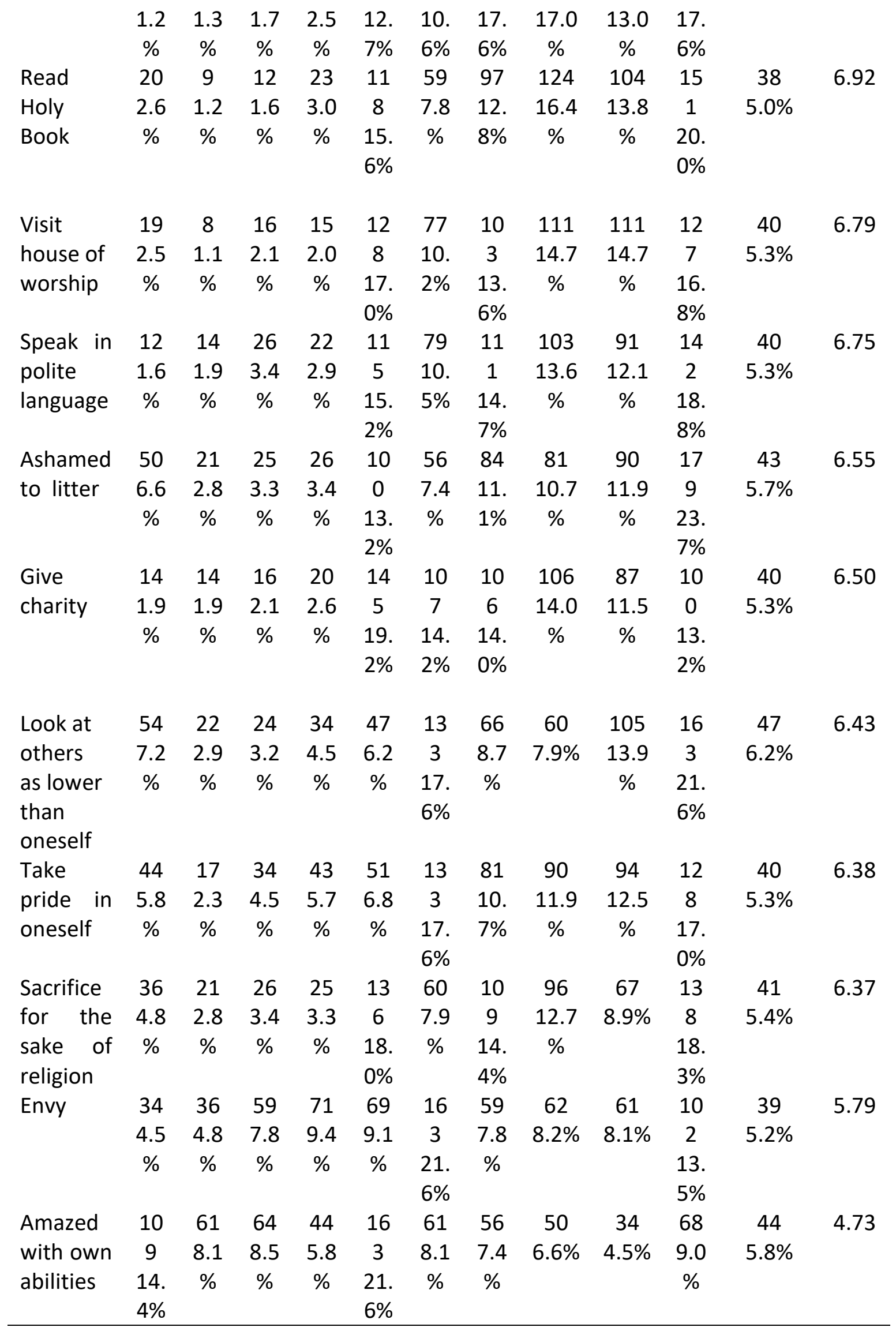


Table 2 showed that among the spiritual practices most frequently done by respondents are prayer (mean=8.22) followed by fasting (mean=8.07), supplicatory prayer (mean=7.97) and being grateful (mean=7.75). This finding is in line with a study by Musa (2015) which shows that the more spiritual practices done, the higher the spiritual and religious well-being attained by university students in Jordan. This finding is almost the same with a study by Carr \& Kroth (2017) which found that research respondents carried out spiritual practices such as solah (prayer), fasting and ibadah (acts of devotion) for the purpose of getting closer to God and going through the process of self-transformation.

Generally, research respondents apply moral values in their spiritual practices such as helping others (mean=7.46), thinking well of others (mean= 7.10), honesty (mean=6.98), reading holy book (mean=6.92), visiting house of worship (mean=6.79), speaking in polite language (mean=6.75), ashamed to litter (mean=6.55), give charity (mean=6.50), and sacrifice for the sake of religion (mean=6.37). These are among the moral values which the Gen Z should apply in order to have a good personality and exemplary character. This study finding that shows respondents love to help others (mean=7.46) is in line with a study by Mohd. Khairi \& Mohamad Khairi (2016) which found that the item 'I will immediately help others in need" achieved a high mean value (mean=4.51).

Even so, this research also finds that there are bad spiritual practices by the respondents such as looking down on or seeing others as lower than themselves (mean $=6.43$ ), self-pride (mean=6.38), envy (mean=5.79) and amazed at his own abilities (mean=4.73) which may infer that respondents possess arrogance, self-pride, ujub (self-admiration) and envy for others. This attitude needs to be shunned because it has a bad effect on human life such as leading to selfishness, feeling he is the greatest, avoiding responsibility, blaming others, always objecting and difficulty in accepting others opinions (Pasha 2002). Envy also needs to be avoided as envy does not bring any good except sins because envy will lead one to gossip, abuse, insult and speak ill of the person envied (al-Ghazali 2000). This negative attitude should be avoided by the Gen Z in order to create and maintain social harmony. In addition, research results find a positive and significant relationship between lifestyle activities and spiritual practices among adolescents of Gen Z $(r=0.469 ; p<0.01)$. High spiritual practices have a relationship with a positive lifestyle (Table 3 ).

Table 3: Relationship between spiritual practices and adolescent lifestyle

\begin{tabular}{lc}
\hline Variable & Value $r$ \\
\hline Spiritual practice & $.469 * *$ \\
Lifestyle & \\
$* * 00.01$ &
\end{tabular}

This finding shows that spiritual practices to some extent reflect a person's lifestyle. The reason is that in religion, a person has certain responsibilities which need to be fulfilled in daily life. A person who adheres to religious teachings would certainly spend some of his time in fulfilling his religious obligations. This clearly shows that religious practice and lifestyle cannot be separated in life except for the individual who has no religion. This finding is in line with a study which found that religion and spirituality play a very important role in human life. Religion plays various roles such as it gives peace of mind, gives strength to face the trial of ill-health, assists in self-transformation, builds positive emotions and reduces feelings of 
depression (Emlet et al. 2018; Van de Velde et al. 2017; Carr \& Kroth 2017; Wendt et al. 2017; Van Cappellen et al. 2016; Abdullah et al., 2016; Gopal, 2014; Mokhtar \& Albaraka, 2016; Hamjah et al.2017; Hamjah \& Mohd. Arib, 2015).

\section{Conclusion}

This research showed that the Gen $Z$ are very much concerned with personal hygiene, emphasize on balanced diet and maintain sufficient sleep hours at night to complete their lifestyle activities. The Gen $Z$ in this research are also very much concerned with spiritual practices in their lives and among the most frequent spiritual practices observed are prayers (solah), fasting (sawm), supplicatory prayer (doa) and being grateful (shukr). This research also finds a significant relationship between lifestyle and spiritual practices of respondents. This study implied that spiritual practices is very critical for comendable Gen Z lifestyle.

\section{Author Contributions}

All the authors have participated sufficiently in this work. The authors are fully responsible for the contents of the paper and the authors are fully responsible for any plagiarism or other issues arising from this paper.

\section{Conflict of interest}

No conflicts of interest have been declared.

\section{Acknowledgement}

This article is an output of research conducted under Geran Universiti Penyelidikan (GUP2020-055), Universiti Kebangsaan Malaysia and Fundamental Research Grant Scheme (FRGS), Ministry of Higher Education, Malaysia, Project Code FRGS/1/2014/SS109/UKM/02/6.

\section{References}

Abdullah, B. (2014) Pembuangan bayi penyebab Wujudnya Anak Pungut : Hukum dan Penyelesaiannya. Journal of Fatwa Management and Research. 4, 161-176. Retrieved from http://jfatwa.usim.edu.my/index.php/jfatwa/article/view/99/81.

Abdullah, K. H. A., Saini, M. S., Sharip, S., \& Shaharom, M. H. (2016). Seeking help at an Islamic spiritual healing centre: Malaysia's perspective. Mental Health, Religion and Culture, 19(7), 742-751. doi.org/10.1080/13674676.2016.1277986.

Adler, A. (1956) The Individual Psychology of Alfred Adler. New York: Basic Books, Inc.

Ahmad, M. I., Haikal, A. A., Abd Satar, J., Shahrazad, W. S., Azreena, W. J., Abidin, Z. J., \& Zain, W. M. S. (2015) Faktor dan Cara Gaya Hidup Serta Kemungkinan Kembali Pulih dalam Kalangan Lesbian : Satu Kajian Kes. Journal of Social Sciences and Humanities, e-Bangi, 10(1), 1-15 (In Malay). Retrieved from http://ejournal.ukm.my/ebangi/article/view/11032

Ahmad, S. (2019). Qur'anic Guidelines for Personality Development and Collective Work. Is/āmiyyāt, 41(1), 109-116.

Al-Ghazali, A. B., Muhammad, A. (2000) Ihya' 'Ulum al-Din. Kaherah: Dar al-Taqwa li al-Turath.

Almeida, J., Johnson, R. M., Corliss, H. L., Molnar, B. E., \& Azrael D. (2009) Emotional Distress among LGBT Youth: The Influence of Perceived Discrimination Based on Sexual Orientation. Journal of Youth and Adolescence. 38(7),1001-1014. doi: 10.1007/s10964009-9397-9 
Amir, N. (2007) Gangguan Tidur pada Lanjut Usia Diagnosis dan Penatalaksanaan Bagian Psikiatri, Fakultas Kedokteran, Universitas Indonesia Rumah Sakit Umum Pusat Nasional Dr Cipto Mangunkusumo, Jakarta. Cermin Dunia Kedokteran. 157, 199.

Bilal, U., \& Padilla-Bernaldez, J. (2016) Cancer and meat consumption: beyond individual life styles. Gaceta Sanitaria, 30(4), 318-318. doi: 10.1016/j.gaceta.2016.03.008.

Brunso, K., Scholderer, J., \& Grunert, K. G. (2004) Closing the gap between values and behavior - a means-end theory of lifestyle. Journal of Business Research, 57(6), 665-670. doi: 10.1016/S0148-2963(02)00310-7

Budhathoki, S. S., Bhattachan, M., Castro-Sanchez, E., Sagtani, R. A., Rayamajhi, R. B., Rai, P., \& Sharma, G. (2018) Menstrual hygiene management among women and adolescent girls in the aftermath of the earthquake in Nepal. BMC Womens Health. 18(33), 1-8. doi: 10.1186/s12905-018-0527-y.

Cankovic, D., Cankovic, S., Cankovic, M., Harhaji, S., \& Radic, I. (2016) The Association between Socio-economic and Life-style Factors and Oral Hygiene among Serbian Adults. European Journal of Public Health. 26, Issue suppl_1, ckw166.035

Carr-Chellman, D. J., \& Kroth, M. (2017). The Spiritual Disciplines as Practices of Transformation. International Journal of Adult Vocational Education and Technology. 8(1), 23-35. doi: 10.4018/ijavet.2017010103

Chang, L. Y., Chang, H. Y., Lin, L. N., Wu, C. C., \& Yen, L. L. (2018) Transitions in sleep problems from late adolescence to young adulthood: A longitudinal analysis of the effects of peer victimization. Aggressive Behavior. 44(1), 69-82. doi: 10.1002/ab.21725.

Corn, B. W., Chochinov, H. M., \& Vachon, M. (2012) Integrating spiritual care into the practice of oncology. Current Opinion in Supportive and Palliative Care. 6(2), 226-227.

Dedeli, O., Yildiz, E., \& Yuksel, S. (2015) Assessing the Spiritual Needs and Practices of Oncology Patients in Turkey. Holistic Nursing Practice. 29(2),103-113. doi: 10.1097/HNP.0000000000000070.

Don, Y. (2000) Penagihan Dadah dan Perlakuan Jenayah: Cabaran kepada Pusat Serenti dan Masyarakat Masa Kini. Seminar Kebangsaan Kerja Sosial , 26-27 Januari 2000, Pusat Konvensyen, Universiti Utara Malaysia (In Malay).

Egan, R., Macleod, R., Jaye, C., Mcgee, R., Baxter, J., Herbison, P., \& Wood, S. (2017) Spiritual beliefs, practices, and needs at the end of life: Results from a New Zealand national hospice study. Palliative \& Supportive Care. 15(2), 223-230. doi: $10.1017 /$ S147895151600064X.

Emlet, C. A., Harris, L., Pierpaoli, C. M., \& Furlotte, C. (2018) The Journey I Have Been Through": The Role of Religion And Spirituality In Aging Well Among HIV-Positive Older Adults. Research on Aging. 40(3), 257-280. doi: 10.1177/0164027517697115.

Engel, J. F., Blackwell, R. D., \& Miniard, P. W. (1995) Consumer Behaviour. Eight Edition. The Dryden Press.

Fareed, M., Salam, N., Khoja, A. T., Mahmoud, M. A., \& Ahamed, M. (2017) Life Style Related Risk Factors of Type 2 Diabetes Mellitus and Its Increased Prevalence in Saudi Arabia: A Brief Review. International Journal of Medical Research \& Health Sciences. 6(3), 125132.

Ghazali, M., Noah, S., Hassan, S. A., \& Jaafar, W. M. (2017) Hubungan Persepsi Kesejahteraan (PK), Kecerdasan Emosi (KE), Kecerdasan Spiritual (KS) dan Efikasi Kendiri Kaunseling (EKK) Terhadap Perkembangan Diri (PD) Kaunselor Pelatih. Jurnal Kurikulum \& Pengajaran Asia Pasifik, 5(3), 1-11 (In Malay). 
Gonzalez-Hernandez, J., Lopez-Mora, C., Portolea-Arino, A., Munoz-Villena, A. J., \& MendozaDiaz, Y. (2017) Psychological Well-Being, Personality and Physical Activity. One Life Style for the Adult Life. Accion Psicologica. 14(1), 65-78. doi: 10.5944/ap.14.1.19262.

Guz, H., Gursel, B., \& Ozbek, N. (2012) Religious and Spiritual Practices Among Patients with Cancer. Journal of Religion \& Health. 51(3), 763-773. doi: 10.1007/s10943-010-9377-0.

Hafford-Letchfield, T., Simpson, P., Simpson, P., \& Almack, K. (2018) Developing inclusive residential care for older lesbian, gay, bisexual and trans (LGBT) people: An evaluation of the Care Home Challenge action research project. Health \& Social Care in the Community. 26(2), E312-E320. doi: 10.1111/hsc.12521.

Hamjah, H. S., Akhir, M. N. S., Ismail, Z., Ismail, A. D., \& Mohd. Arib, N. (2017) The Application of Ibadah (Worship) in Counseling: Its Importance and Implications to Muslim Clients. Journal of Religion and Health. 56 (4) : 1302-1310. doi.org/10.1007/s10943-015-0122-6

Hamjah, H. S., \& Mohd. Arib., N. (2015). Discussion on Religious Practice in Counseling : A reliminary Survey. Mediterranean Journal of Social Sciences. 6 (6)S5, 394-401. doi:10.5901/mjss.2015.v6n6s5p394.

Hasan, H. (1998) Pelacuran di kalangan wanita Melayu Kelantan dari 1900 sehingga 1941. Ph.D thesis. Universiti Malaya. Kuala Lumpur. (In Malay)

Hong, K. S., George, T. G. S., Gan, S. L., Peter, S., Othman, A. E., Usop, H., Othman, M. R., Ridzuan, A. A., Arabi, H., \& Adruce, Z. S. A. (2011) Penyalahgunaan Bahan Di Kalangan Remaja: Satu Kajian Di Sekolah Menengah Sarawak. Jurnal Antidadah Malaysia. 8(2), 118 (In Malay).

Hou, C., Zheng, B., Yang, Y., Wang, X. G., Zhang, B., Shi, Q. P., \& Chen, M. (2017) Weight reduction via life-style modifications results in reverse remodelling and cardiac functional improvement in a patient with obesity. Obesity Research \& Clinical Practice. 11(3), 364-369. doi: 10.1016/j.orcp.2017.07.003.

Husain, S. (2009) Persepsi Mahasiswa SPI Terhadap Amalan Gaya Hidup Sihat Menurut Islam dalam Aspek Penjagaan Kesihatan Dan Pemakanan. (Perception of SPI Undergraduates towards Islamic Practice of Healthy Lifestyle in Healthcare and Nutrition). Skudai: Universiti Teknologi Malaysia. Ijazah Sarjana Muda Sains Serta Pendidikan (Pengajian Islam).

Kapelios, C. J., Kyriazis, I., loannidis, I., Dimosthenopoulos, C., Hatziagelaki, E., \& Liatis, S. (2017). Diet, life-style and cardiovascular morbidity in the rural, free living population of Elafonisos Island. BMC Public Health. 17. Article Number: 147. doi: 10.1186/s12889017-4053-x.

Kawahara, K., \&Yuki, M. (2001) Relationship between health perceptions and life style in the elderly. Gerontologist. 41, Special Issue 1, 200-200.

Klingle, K. E., \& Van Vliet, K. J. 2019. Self-Compassion From the Adolescent Perspective: A Qualitative Study. Journal of Adolescent Research. 34(3), 323-346. doi: 10.1177/0743558417722768.

Lau, X. C., Wong, Y. L., Wong, J. E., Koh, C. L. D., Sedek, R., Jamil, A. T., \& Poh, B. K. (2019). Development and Validation of a Physical Activity Educational Module for Overweight and Obese Adolescents: CERGAS Programme. International journal of environmental research and public health, 16(9). doi.org/10.3390/ijerph16091506.

Li, Y. P., Wang, D. D., Ley, S. H., Howard, A. G., He, Y. N., Lu, Y., Danaei, G., \& Hu, F. B. (2016) Potential Impact of Time Trend of Life-Style Factors on Cardiovascular Disease Burden in China. Journal of the American College of Cardiology. 68(8), 818-83. doi: 10.1016/j.jacc.2016.06.011. 
Lotfi, M., Hosseini, S., Rafie, A., Dostifar, K., \& Dostifar, K. (2017)

A Study on the Life Style of High School Girls in Relation to the Prevention of Osteopor osis, Ahvaz, Iran. International Journal of Advanced Biotechnology and Research. 8(4), 371-379.

Manap, J., Hamzah, M. R., Saim, N. J., \& Izani, M. N. N. (2015) The Definition of Gen Z: A systematic review. Paper presented in Indonesia - Malaysia Culture Symposium, Everly Hotel, Putrajaya.

Manap, J., Hamzah, M. R., Amin, A. S., Idris, F., Che Kasim, A., Hamjah, H. S., Tambi, N., Sarnon, N., Nen, S., Saim, N. J., \& Izani, M. N. N. (2016) Profil Generasi Z. Unpublish material.

Miri, S. F., Javadi, M., Lin, C. Y., Irandoost, K., Rezazadeh, A., \& Pakpour, A. H. (2017) Health Related Quality of Life and Weight Self-Efficacy of Life Style among Normal-Weight, Overweight and Obese Iranian Adolescents: A Case Control Study. International Journal of Pediatrics-Mashhad. 5(11), 5975-5984. doi: 10.22038/ijp.2017.25554.2173.

Zin, M. Z. (2016) Kebersihan Tangan Warnai Sambutan 'World Hygiene Day 2016'. Malaysia Aktif. Retrieved from http://malaysiaaktif.my/malaysiaaktif2/.

Mohd, A. \& Alkali, A. U. (2015) Crime of Baby Dumping: A Review of Islamic, Malaysian and Nigerian Laws. Pertanika Journal of Social Science and Humanities. 23, 67-82.

Mohd. Jaafar, N. A., Singh, N., Awang, M. M., Mydin, F., Ahmad, A. R. (2014) Tren penyalahgunaan dadah dalam kalangan mahasiswai (2008-2013). In International Social Development Conference 2014 (ISDC 2014), 12 - 13 August, Bayview Hotel Langkawi, Malaysia.

Tahir, M. R., Sa'ari, H., \& Johare, R. (2017) Studies pertaining to Illegal Street Racers' Behaviour: Literature Review. International Journal of Academic Research in Business and Social Sciences. 7(6), 315-325.

Mokhtar, A. I., \& Albaraka, J. I. (2016). Publications in the maqasid Al-Shari'ah. Global Journal Al-Thaqafah, 6(2), 157-170. doi: 10.7187/GJAT12120160602

Mourouti, N., Kontogianni, M. D., Papavagelis, C., Plytzanopoulou, P., Vassilakou, T., Psaltopoulou, T., Malamos, N., Linos, A., \& Panagiotakos, D. B. (2015) Meat consumption and breast cancer: a case-control study in women. Meat Sci. Feb.100, 195-201. doi:10.1016/j.meatsci.2014.10.019.

Musa, A. (2015) Spiritual Beliefs and Practices, Religiosity, and Spiritual Well-Being among Jordanian Arab Muslim University Students in Jordan. Journal of Spirituality In Mental Health. 17(1), 34-49. https://doi: 10.1080/19349637.2014.957609.

Palmer, C. A., Oosterhoff, B., Bower, J L., Kaplow, J. B., \& Alfano, C. A. (2018) Associations among adolescent sleep problems, emotion regulation, and affective disorders: Findings from a nationally representative sample. Journal of Psychiatric Research. 96, 1-8. doi: 10.1016/j.jpsychires.2017.09.015.

Papaioannou, T. G., Karatzi, K., Psaltopoulou, T., \& Tousoulis, D. (2017) Arterial ageing: Major nutritional and life-style effects. Ageing Research Reviews. 37, 162-163. doi: 10.1016/j.arr.2016.10.004.

Pasha, M. K. (2002). Qalbun Salim Hiasan Hidup Muslim Terpuji. Jogjakarta: Citra Karsa Mandiri (In Indonesia)

Patimah, S., Royani, I., Mursaha, A., \& Thaha, A. R. (2016) Knowledge, attitude and practice of balanced diet and correlation with hypochromic microcytic anemia among adolescent school girls in Maros district, South Sulawesi, Indonesia. Biomedical Research-India. 27(1), 165-171. doi : 10.7187/GJAT12120160602 
Peltzer, K., \& Pengpid, S. (2014). Oral and Hand Hygiene Behaviour and Risk Factors among InSchool Adolescents in Four South-east Asian Countries. International Journal of Environmental Research and Public Health. 11(3), 2780-2792. doi: 10.3390/ijerph110302780.

Puaca, G., Theandersson, C., \& Carlen, M. (2017) Resisting consumerist rationalities in higher vocational education. Journal for Critical Education Policy Studies. 15(1), 205-227.

Raifman, J. (2018) Primary Care for LGBT Adolescents: Patient and Provider Perspectives. Journal of Adolescent Health. 62(2), S43-S43.

Ramachandaran, S. D., Krauss, S. E., Hamzah, A., \& Idris, K. (2017) Effectiveness of the Use of Spiritual Intelligence in Women Academic Leadership Practice. International Journal of Educational Management. 31(2), 160-178. doi: 10.1108/IJEM-09-2015-0123

Safuwan, M. P. (2007) Gaya Hidup, Konsumerisme dan Modernitas (Lifestyle, Consumerism and Modernity). Jurnal SUWA Universitas Malikussaleh, V(1), 38-46.

Sagayadevan, V., Abdin, E., Binte Shafie, S., Jeyagurunathan, A., Sambasivam, R., Zhang, YJ., Picco, L., Vaingankar, J., Chong, SA., \& Subramaniam, M. (2017) Prevalence and correlates of sleep problems among elderly Singaporeans. Psychogeriatrics. 17(1), 4351. doi: $10.1111 /$ psyg.12190

Shinohara, H., Okuda, T., Tanaka, N., \& Hamaguchi, I. (2017) Dietary Habits and LifeStyle Factors Influence The Health-Related Quality of Life and the Learning Attitude In Schoolchildren. Annals of Nutrition and Metabolism. 71, 632-632.

Shrivastava, A., Sharma, M. K., \& Marimuthu, P. (2018) Internet addiction at workplace and its implication for workers' life style: Exploration from Southern India. Asian Journal of Psychiatry. 32, 151-155. doi: 10.1016/j.ajp.2017.11.014

Spitz, J., Jordan, A., Spitz, A., \& Thoennissen, N. (2017) Medical Thesis: Combining Vitamin D Supplementation with Multiple Established Life Style Interventions to Overcome Cancer. Anticancer Research. 37(6), 3353-3354.

Tarigan, D. I. M. (2015) Kajian Gaya Hidup Masyarakat Di Kelurahan Bahu, Kecamatan Malalayang, Kota Manado. e-journal Acta Diurna. IV(4). (In Malay)

Taspcott, D. (2008) Grown-up Digital: How the Net Generation is Changing Your World. McGraw-Hill.

Thompson-McCormick, J. J., Thomas, J. J., Bainivualiku, A., Khan, A., \& Becker, A. E. (2010). Breakfast Skipping as a Risk Correlate of Overweight and Obesity in School-going Ethnic Fijian Adolescent Girls. Asia Pacific Journal of Clinical Nutrition, 19(3), 372.

Thune-Boyle, I. C. V., Stygall, J., Keshtgar, M. R. S., Davidson, T. I., \& Newman, S. P. (2011) The Impact of a Breast Cancer Diagnosis on Religious/Spiritual Beliefs and Practices in the UK. Journal of Religion \& Health. 50(2), 203-218. doi: 10.1007/s10943-010-9322-2.

Tohri, T. (1998) Masalah Pelacuran: Kajian Perbandingan mengenai Pemulihan Sosial di Indonesia dan Malaysia. Kuala Lumpur: Masters thesis, University of Malaya.

Ueki, A., \& Otsuka, M. (2004) Life style risks of Parkinson's disease: Association between decreased water intake and constipation. Journal of Neurology. 251, (7), VII/18-VII/23 doi: 10.1007/s00415-004-1706-3

Van Cappellen, P., Toth-Gauthier, M., Saroglou, V., \& Fredrickson, B. L. (2016) Religion and Well-Being: The Mediating Role of Positive Emotions. Journal of Happiness Studies. 17(2), 485-505. doi: 10.1007/s10902-014-9605-5

Van de Velde, S., Van der Bracht, K., \& Buffel, V. (2017) The relation between religion and depression in Europe: The moderating role of the religious context. International Journal of Comparative Sociology. 58(6), 515-532. doi: 10.1177/0020715217736361. 
Van der Schuur, W. A., Baumgartner, S. E., Sumter, S. R., \& Valkenburg, P. M. (2018) Media multitasking and sleep problems: A longitudinal study among adolescents. Computers in Human Behavior. 81, 316-324. doi: 10.1016/j.chb.2017.12.024.

Wendt, D. C., Collins, S. E., Nelson, L. A., Serafini, K., Clifasefi, S. L., \& Donovan, D. M. (2017) Religious And Spiritual Practices Among Homeless Urban American Indians and Alaska Natives with Severe Alcohol Problems. American Indian and Alaska Native Mental Health Research. 24(3), 39-62. doi : 10.5820/aian.2403.2017.39

Whelan-Gales, M. A., Griffin, M. T. Q., Maloni, J., \& Fitzpatrick, J. J. (2009) Spiritual WellBeing, Spiritual Practices, and Depressive Symptoms among Elderly Patients Hospitalized with Acute Heart Failure. Geriatric Nursing. 30(5), 312-317. doi: 10.1016/j.gerinurse.2009.04.001.

Wong, L. P. (2011) Socio-demographic and behavioural characteristics of illegal motorcycle street racers in Malaysia. BMC Public Health. 11. Article Number: 446. doi : 10.1186/1471-2458-11-446.

Yu, J. H., Mahendran, R., Abdullah, F. N. M., Kua, E. H., \& Feng, L. (2017) Selfreported Sleep Problems among the Elderly: A Latent Class Analysis. Psychiatry Research. 258, 415-420. doi: 10.1016/j.psychres.2017.08.078. 